\title{
ANNUAL GENERAL MEETING OF THE FPS
}

THE President, the Marquess of Willingdon, took the chair at the Annual 1 General Meeting of the FPS, held at the offices of the Zoological Society of London, on April 29th, 1964. The minutes of the previous annual general meeting were approved and signed, and both the Auditors' Report and the Council's Annual Report were approved and adopted. The Marquess of Willingdon was re-elected President and Mr. I. D. Malcolmson Honorary Treasurer. Lord Willingdon welcomed Mr. and Mrs Fitter as, respectively, Honorary Secretary and Editor of ORYX, and expressed the sincere thanks of the Society to the retiring Secretary, Colonel Boyle, and to Mrs Boyle for all that they had done, and also the Society's regret at the resignation of Mr. John Hillaby, the Public Relations Officer. The President spoke of the need for all conservation organisations to work together, instancing the FPS, the Council for Nature, and the World Wildlife Fund, and hoped that closer links in the whole movement would be made. He thanked Sir Solly Zuckerman and the Zoological Society of London for providing the Society with office accommodation and for other help.

After expressing the Society's warm thanks to the three retiring members of the council-Dr. F. Fraser Darling, Mr. James Fisher and Mr. E. O. Shebbeare-the President proposed the election in their place of Mr. David Attenborough, Lord Craigton and Mr. R. C. Morris, and this was carried unanimously. Following the business, Mr. Fitter gave a brief account of the M'lilwane Game Sanctuary, the only wildlife sanctuary in Swaziland, which had been started by Mr. T. E. Reilly, a young and enthusiastic conservationist who had put all his personal savings into the project, and to whom the Society had sent a gift of $f, 100$. He also showed some slides of the sanctuary. In an illustrated talk Dr. R. M. Laws, of the Nuffield Unit of Tropical Ecology in Uganda, spoke on "The Ecology and Management of Hippopotamus in Uganda", and showed how a successful cropping scheme had been launched to cope with the overpopulation of the hippos in Queen Elizabeth National Park, and the beneficial effect of this on the habitat.

\section{PESTICIDES AND WILDLIFE}

GEVERAL important developments in relation to the effects of pesticides

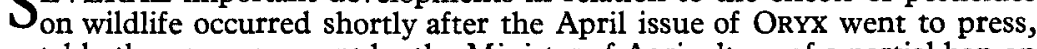
notably the announcement by the Minister of Agriculture of a partial ban on aldrin, dieldrin, and heptachlor. The fourth report of the Joint Committee of the British Trust for Ornithology and the Royal Society for the Protection of Birds showed that it is now the garden and insectivorous birds which head the list of birds affected by the chlorinated hydrocarbons. During the year, 304 out of 333 birds and forty-two out of forty-six samples of eggs analysed proved to contain varying quantities of chlorinated hydrocarbon pesticides, including sixty incidents relating to thirteen different kinds of birds of prey. Every one of eight samples of slugs and worms from fields and gardens treated with aldrinated fertilisers contained residues of dieldrin and DDT or its metabolites. The Committee seeks ultimately a complete ban on all chlorinated hydrocarbons, which it appreciates may be economically impossible at present.

At the international conference on birds of prey at Caen in April, reported on page 208 , one of the main recommendations was that the manufacture, storage, exportation, importation, sale, purchase and use in agriculture, forestry and similar activities of toxic chemicals as pesticides should be 